\title{
Composition and properties of bovine colostrum: a review
}

\author{
Brian A. McGrath ${ }^{1,2} \cdot$ Patrick F. Fox ${ }^{1}$. \\ Paul L. H. McSweeney ${ }^{1}$ - Alan L. Kelly ${ }^{1,2}$
}

Received: 29 April 2015 / Revised: 28 August 2015 / Accepted: 28 August 2015 /

Published online: 14 September 2015

(C) INRA and Springer-Verlag France 2015

\begin{abstract}
Colostrum is the initial milk secreted by mammals following parturition, the composition and physicochemical properties of which are highly dynamic and variable. The composition and physicochemical properties of colostrum during the initial postpartum period has not been systematically reviewed for many years, although the topic remains of interest both to milk producers and processors. In this article, the current understanding of the composition of colostrum, i.e. carbohydrates, proteins, growth factors, enzymes, enzyme inhibitors, nucleotides and nucleosides, cytokines, fats, vitamins and minerals, is reviewed. In addition, the physicochemical properties, i.e. $\mathrm{pH}$ and buffering capacity, colour, density and specific gravity, osmotic pressure, somatic cell count, properties of casein micelles, ethanol stability and rennet coagulation properties are discussed, as well as the effects of heat-treating colostrum.
\end{abstract}

Keywords Colostrum $\cdot$ Milk $\cdot$ Composition $\cdot$ Physicochemical properties · Lactation

\section{Introduction}

Milk is a fluid secreted by the female of all mammalian species, the primary function of which is to meet the complete nutritional requirements of the neonate, while also serving several physiological functions. Colostrum is the secretion produced by the mammary gland immediately following parturition.

In the case of cows, the duration for which the mammary secretion is classified as colostrum rather than milk varies considerably amongst different reports, i.e. immediately after parturition (Levieux and Ollier 1999; Nakamura et al. 2003; Godhia and Patel 2013), 2 days (Playford et al. 2000; Playford 2001), 3 to 4 days (Foley and

Alan L. Kelly

a.kelly@ucc.ie

1 School of Food and Nutritional Sciences, University College Cork, Cork, Ireland

2 Food for Health Ireland, University College Cork, Cork, Ireland 
Otterby 1978; Gopal and Gill 2000; Davis et al. 2007; Zhang et al. 2011) or 5 to 7 days post-partum (Marnila and Korohnen 2002; Georgiev 2008; Zarcula et al. 2010; Abd ElFattah et al. 2012). For the purposes of this review, colostrum, unless otherwise defined, will refer to the early milkings from dairy cows, taken up to 3 days post-partum.

The composition and physical properties of colostrum are highly variable due to a number of factors, including individuality, breed, parity, pre-partum nutrition, length of the dry period of cows and time post-partum (Parrish et al. 1947, 1948, 1949; Moody et al. 1951). In general, colostrum contains less lactose and more fat, protein, peptides, non-protein nitrogen, ash, vitamins and minerals, hormones, growth factors, cytokines and nucleotides than mature milk; except in the case of lactose, the levels of these compounds decrease rapidly during the first 3 days of lactation (Blum and Hammon 2000a, b; Uruakpa et al. 2002). Colostrum is characterised by its very high concentration of immunoglobulin $\mathrm{G}(\mathrm{IgG})$, which is of particular importance to the neonate, whose gut, immediately following parturition, allows the passage of large immunoglobulins, thereby conferring passive immunity (Marnila and Korohnen 2002; Tsioulpas et al. 2007; Stelwagen et al. 2009). It is essential that the newborn calf receives an adequate supply of colostrum as both the concentration of immunoglobulins and permeability of the gut decrease rapidly over the first $24 \mathrm{~h}$ following parturition (Weaver et al. 2000; Moore et al. 2005). In addition, colostrum intake influences metabolism, endocrine systems and the nutritional state of neonatal calves (Guilloteau et al. 1997; Blum and Hammon 2000a, b) and stimulates the development and function of the gastrointestinal tract (Hadorn et al. 1997; Guilloteau et al. 1997; Buhler et al. 1998; Blum and Hammon 2000a, b). Up to $60 \%$ of colostrum produced on US dairy farms does not meet the minimum immunological and bacteriological standards, i.e. $>50$ g. $\mathrm{L}^{-1}$ of $\mathrm{IgG}$ and a total plate count of $<100,000 \mathrm{cfu} . \mathrm{mL}^{-1}$, respectively (Morrill et al. 2012). Limited work has been carried out investigating the efficacy of heat-treating colostrum from an immunological and bacteriological viewpoint.

Colostrum accounts for approximately $0.5 \%$ of a cow's annual milk output (Scammell 2001). Most healthy dairy cows produce colostrum far in excess of the calf's requirements (Oyeniyi and Hunter 1978), but, typically, milk collected during the colostrum period is considered unmarketable (Foley and Otterby 1978) and often is excluded from bulk milk collection (Marnila and Korohnen 2002). The high protein content of colostrum leads to multiple problems in industrial processes, e.g. poor heat stability, which interferes with pasteurisation (Marnila and Korohnen 2002; McMartin et al. 2006). Also, the high content of antimicrobial components in colostrum may affect the fermentation process (Marnila and Korohnen 2002). Despite this, colostrum has attracted considerable interest as a functional food ingredient (Korohnen 1998).

Foley and Otterby (1978) reviewed the literature on the composition of colostrum, but, to the best of the authors' knowledge, no comprehensive review on the composition of colostrum has been published since. Changes in the composition and physical properties of milk throughout lactation have been studied extensively (White and Davies 1958a, b, c; Cerbulis and Farrell, 1976; Donnelly and Horne, 1986; Horne et al., 1986; Rodriguez et al., 2001); however, little is known about the composition and stability of colostrum. The objectives of this review are to discuss the composition and properties of bovine colostrum. 


\section{Chemical constituents of colostrum}

\subsection{Carbohydrate}

\subsubsection{Lactose}

The concentration of lactose is low in colostrum and changes in an inverse manner to other constituents such as fat, protein and ash (Parrish et al. 1950; Kehoe et al. 2007). A low level of lactose in early post-partum milkings, followed by a steady increase thereafter, until a normal level is reached, has been reported by several authors (Parrish et al. 1948, 1950; Klimes et al. 1986; Madsen et al. 2004; Kehoe et al. 2007; Tsioulpas et al. 2007; Georgiev 2008; El-Fatah et al. 2012; Morrill et al. 2012). Lactose concentrations as low as $1.2 \%$ have been reported in colostrum (Kehoe et al. 2007; Morrill et al. 2012). In general, lactose concentration reaches a normal concentration within 7 days post-partum. Tsioulpas et al. (2007) reported that the lactose content of milk did not reach normal levels until 60 days post-partum; however, in this particular study, no samples were collected between 30 and 60 days post-partum.

Lactose is responsible for about $50 \%$ of the osmotic pressure of milk (Fox 2009a, b); its production causes the movement of water from the cytoplasm of mammary epithelial cells into the secretory vesicles and subsequently into milk. This influx of water into milk regulates the volume of milk produced and the concentration of casein in milk (Jenness and Holt 1987). A low level of lactose results in the production of milk that is extremely viscous and contains little water due to the absence of the osmoregulator lactose (Bleck et al. 2009).

Madsen et al. (2004) reported the density of the first milk post-partum to be 1.048 g.mL $\mathrm{mL}^{-1}$, which is significantly higher than the average density of milk (1.029 g.mL ${ }^{-1}$; Walstra et al. 2006). This value decreased over the first six milkings until a normal level was reached, while in parallel the lactose concentration increased from 2.6 to 4.4\% (Madsen et al. 2004). Similarly, Strekozov et al. (2008) reported that the density of first milk post-partum from 62 cows ranged from 1.054 to $1.072 \mathrm{~g} \cdot \mathrm{mL}^{-1}$. In order to maintain osmotic pressure, milk with a low level of lactose has an elevated level of inorganic salts (Holt and Jenness 1984).

\subsubsection{Oligosaccharides}

In addition to lactose, milk contains trace amounts of other sugars, including glucose, fructose, glucosamine, galactosamine, $\mathrm{N}$-acetylneuraminic acid and oligosaccharides, defined as carbohydrates that contain 3 to 10 monosaccharides covalently linked through glycosidic bonds. Oligosaccharides are divided into two broad classes, i.e. neutral and acidic. Neutral oligosaccharides, or galacto-oligosaccharides (GOS), contain no charged carbohydrate residues, whereas acidic oligosaccharides contain one or more negatively charged residues of $\mathrm{N}$-acetylneuraminic acid (sialic acid) (Gopal and Gill 2000).

The concentration of oligosaccharides in colostrum is approximately 0.7 to 1.2 g.mL ${ }^{-1}$ (Nakamura et al. 2003), the majority of which are acidic, whereas mature milk contains only trace amounts (Gopal and Gill 2000). To date, 40 oligosaccharides 
have been identified in bovine colostrum (Tao et al. 2008, 2009; Barile et al. 2010). The total number of oligosaccharides in colostrum varies between individual cows due to unique genetic variability (Ninonuevo et al. 2006). In one study, the total number of oligosaccharides in colostrum from individual cows ranged between 14 and 32 (Barile et al. 2010). 3' Sialylactose (3'SL), 6' sialylactose (6'SL), 6' sialylactosamine (6'SLN) and disialyllactose (DSL) are the predominant oligosaccharides in colostrum, with 3'SL accounting for $70 \%$ of the total oligosaccharide content (Martin-Sosa et al. 2003; Nakamura et al. 2003; McJarrow and van Amelsfort-Schoonbeek 2004; Tao et al. 2009; Urashima et al. 2009). Nakamura et al. (2003) reported that levels of 3'SL, 6'SL and 6'SLN in colostrum were highest immediately following parturition and decreased rapidly by $48 \mathrm{~h}$ post-partum, whereas levels of neutral oligosaccharides increased. McJarrow and van Amelsfort-Schoonbeek (2004) found the concentrations of 3'SL, 6' SL, 6'SLN and DSL to be 681, 243, 239 and $201 \mathrm{mg} \cdot \mathrm{mL}^{-1}$, respectively, in Holstein colostrum and $867,136,220$ and $283 \mathrm{mg} \cdot \mathrm{mL}^{-1}$, respectively, in Jersey colostrum immediately after parturition.

\subsection{Protein}

The concentration of casein is higher in colostrum than in milk (Cerbulis and Farrell 1975; Madsen et al. 2004) and decreases at each milking post-partum (Parrish et al. 1948). Sobczuk-Szul et al. (2013) reported that early post-partum milk contained reduced proportions of $\alpha_{\mathrm{s}}$-casein, which increased with time post-partum, and elevated proportions of к-casein, which decreased with time post-partum, while the proportion of $\beta$-casein remained constant throughout.

The immunoglobulins, of which there are three major classes in milk, i.e. IgG, $\operatorname{IgM}$ and $\operatorname{IgA}$, account for about $1 \%$ of the total milk protein or about $6 \%$ of the total whey protein (Farrell et al. 2004). Colostrum contains elevated levels of IgG, IgA and IgM (Smolenski et al. 2007), and immunoglobulins make up 70-80\% of the total protein in colostrum (Larson 1992), which is of particular importance to the neonate, as transfer of passive immunity to the calf occurs through colostrum and not via the placenta (Zhang et al. 2011). Changes in the level and relative proportions of the immunoglobulins in colostrum compared with milk have been reported by several authors (Quigley et al. 1994; Levieux and Ollier 1999; Korohnen et al. 2000; Elfstrand et al. 2002; Zhao et al. 2010). The concentration of immunoglobulins in the first milk post-partum can vary considerably, from 30 to $200 \mathrm{mg} \cdot \mathrm{mL}^{-1}$ (Larson 1992; Korohnen et al. 1995; Gapper et al. 2007). IgG1 comprises over 75\% of the Igs in colostrum, followed by IgM, IgA and IgG2 (Butler 1974). It should be noted that different IgG subclasses differ in their biological activities (Akita and Li-Chan 1998). The concentration of immunoglobulins in milk declines rapidly following parturition (Korohnen et al. 2000).

The concentrations of beta-lactoglobulin $(\beta-\lg )$ and alpha-lactalbumin $(\alpha-1 a)$ are higher in colostrum than in mature milk (Marnila and Korohnen 2002; Georgiev 2008). Marnila and Korohnen (2002) reported that the initial concentration of $\beta$-lg in colostrum ranges from 7.9 to $30 \mathrm{mg} \cdot \mathrm{mL}^{-1}$, the average being $14 \mathrm{mg} \cdot \mathrm{mL}^{-1}$ in the first milking and falling sharply thereafter to $8 \mathrm{mg} \cdot \mathrm{mL}^{-1}$ in the second to fourth milkings; the decrease is more gradual until the 16th milking, when the average is $5 \mathrm{mg} \cdot \mathrm{mL}^{-1}$. These results agree with those reported by Levieux and Ollier (1999) and Sobczuk-Szul 
et al. (2013). Marnila and Korohnen (2002) reported that the level of $\alpha$-la in colostrum decreases more gradually from $2 \mathrm{mg} \cdot \mathrm{mL}^{-1}$ in the first milking to $1.4 \mathrm{mg} \cdot \mathrm{mL}^{-1}$ in the 16th milking, which was also reported by Levieux and Ollier (1999). However, Sobczuk-Szul et al. (2013) reported that the initial concentrations of $\alpha$-la in colostrum from Jersey and Polish Holstein-Friesian cows were 13.82 and $7.91 \mathrm{mg} . \mathrm{mL}^{-1}$, respectively. In this particular study, colostrum samples were collected from eight cows, which is a relatively small number and may explain the unusually high levels observed. The ratio of $\beta-\lg / \alpha$-la is four times greater in colostrum than in mature milk, suggesting that $\beta$-lg may play a specific role during the early post-partum period (Perez et al. 1990).

The concentration of bovine serum albumin in colostrum is higher than in milk (Zhang et al. 2011). Perez et al. (1989) reported that the first milk post-partum contains $2.63 \mathrm{mg} \cdot \mathrm{mL}^{-1}$ BSA. This value decreases substantially within $24 \mathrm{~h}$ and reaches normal levels by the second week post-partum $\left(0.2 \mathrm{mg} \cdot \mathrm{mL}^{-1}\right)$. A similar trend was observed by Levieux and Ollier (1999). The increased concentration of BSA in colostrum is a result of increased leakage from the circulating blood (Zhang et al. 2011), which may play a role in the transport of small molecules, i.e. free fatty acids released from adipocytes (Evans 2002).

Lactoferrin is a cationic iron-binding glycoprotein of mammary origin that plays a key role in the defence of the mammary gland (Farrell et al. 2004). The concentration of lactoferrin in milk ranges from 0.02 to $0.75 \mathrm{mg} \cdot \mathrm{mL}^{-1}$ (Hahn et al. 1998; Fox and Kelly 2003). Several authors have reported an increased concentration of lactoferrin in colostrum (Pakkanen and Aalto 1997; Hahn et al. 1998; Zhang et al. 2002, 2011; Sobczuk-Szul et al. 2013). Reiter (1978) reported that the concentration of lactoferrin in colostrum is 30-fold higher than that in milk, while Indyk and Filonzi (2005) observed a 100-fold higher concentration of lactoferrin in colostrum than in milk. It should be noted that, in addition to stage of lactation, lactoferrin concentration is significantly correlated with SCC, level of BSA and volume of milk produced (Cheng et al. 2008). Typically, the concentration of lactoferrin in colostrum ranges from 1.5 to $5 \mathrm{mg} \cdot \mathrm{mL}^{-1}$ (Korohnen 1977; Hahn et al. 1998).

There are few reports in the literature on the occurrence of minor proteins in colostrum because detection and identification of minor proteins is difficult due to the high concentration of the principal proteins, which reduce the detection sensitivity of mass spectrometry. Yamada et al. (2002) used immunoabsorption to remove major proteins from colostrum and milk prior to 2D-PAGE, which enabled the detection of several otherwise undetectable minor proteins; a total of 29 minor proteins were identified in colostrum and milk, of which several were observed only in colostrum, i.e. fibrinogen $\beta$-chain, chitinase 3-like $1, \alpha$-antitrypsin, complement C3 $\alpha$-chain, gelsolin and apolipoprotein H. Smolenski et al. (2007), using a combination of liquid chromatography-mass spectrometry/mass spectrometry (LC-MS/MS) and two-dimensional gel electrophoresis (2-DE) followed by matrix-assisted laser desorption/ionisation time-of-flight mass spectrometry (MALDI-TOF/MS), and D'Amato et al. (2009), using combinatorial peptide ligand libraries, identified 53 and 149 minor proteins in whey from colostrum or milk, respectively, some of which were identified only in colostrum. Using ion-exchange chromatography, Le et al. (2011) identified a total of 293 whey proteins in colostrum and milk, of which 36 were identified exclusively in colostrum. Nissen 
et al. (2012) identified 403 minor proteins in colostrum using 2D-LC-MS/MS, which, to the authors' knowledge, is the most comprehensive characterisation to date of whey proteins in colostrum. In a follow-on study, Nissen et al. (2013), also using 2D-LC-MS/MS, identified a total of 742 minor proteins in milk; however, 366 of these proteins were identified only in one replicate and are therefore regarded as tentative results.

To date, over 120 proteins have been identified in the milk fat globule membrane (MFGM), and changes in the MFGM proteome during the transition from colostrum to milk have been described (Reinhardt and Lippolis 2006). Mucin, butyrophilin, fatty acid-binding protein and xanthine dehydrogenase were up-regulated 2.6-fold to 7.7fold in MFGM from milk compared with colostrum MFGM. Apolipoprotein 1 and clusterin were down-regulated 2.6-fold to 3.6-fold in milk MFGM compared with colostrum MFGM while no changes in the concentrations of polymeric immunoglobulin receptor, peptidylprolyl isomerase $\mathrm{A}, 71 \mathrm{kDa}$ heat-shock cognate protein, cluster of differentiation 36, actin and lactadherin were noted.

\subsection{Growth factors}

The main growth factors in colostrum and milk are epidermal growth factor (EGF) (Yagi et al. 1986; Iacopetta et al. 1992), betacellulin (BTC) (Bastian et al. 2001), insulin-like growth factor I (IGF-I) (Collier et al. 1991), IGF-II (Schams 1994), transforming growth factor- $\beta 1$ (TGF- $\beta 1$ ) (Ginjala and Pakkanen 1998), TGF- $\beta 2$ (Cox and Burk 1991), fibroblast growth factor 1 and 2 (FGF1 and FGF2) (Kirihara and Ohishi 1995) and platelet-derived growth factor (PGDF) (Belford et al. 1997).

In general, the concentrations of growth factors in colostrum are highest during the initial hours post-partum and decline significantly in a time-dependant manner (Collier et al. 1991; Ginjala and Pakkanen 1998; Bastian et al. 2001). The most abundant growth factors in colostrum are IGF-1 and IGF-II (Marnila and Korohnen 2002). Pakkanen and Aalto (1997) reported that the concentrations of IGF-I and IGF-II in colostrum range from 50 to $2000 \mu \mathrm{g} . \mathrm{L}^{-1}$ and $200-600 \mu \mathrm{g} . \mathrm{L}^{-1}$, respectively, whereas mature milk contains $<10 \mu \mathrm{g} . \mathrm{L}^{-1}$ of each. Yagi et al. (1986) found that the concentration of EGF in colostrum and milk was 324 and $155 \mu \mathrm{g} . \mathrm{L}^{-1}$, respectively; however, Iacopetta et al. (1992) reported the concentration of EGF in colostrum and milk to be $4-8$ and $<2 \mu \mathrm{g} . \mathrm{L}^{-1}$, respectively. It should be noted that reported levels of growth factors vary significantly depending on the method of quantitation used. The concentration of TGF- $\beta 1$ in colostrum ranges from 12 to $43 \mu \mathrm{g} . \mathrm{L}^{-1}$, compared with 0.8 to $3.5 \mu \mathrm{g} . \mathrm{L}^{-1}$ in milk (Ginjala and Pakkanen 1998). The concentration of TGF- $\beta 2$ is also higher in colostrum than that in milk (Pakkanen 1998).

\subsection{Enzymes}

Approximately 70 indigenous enzymes have been reported in milk and originate from four principal sources, i.e. blood plasma, secretory cell cytoplasm, milk fat globule membrane (MFGM) and somatic cells (Fox et al. 2003; Fox and Kelly 2006a, b). In general, the enzyme content of colostrum is higher than in milk (Shahani et al. 1973). 


\subsubsection{Antioxidant enzymes}

Lactoperoxidase (LPO) is a member of the peroxidase family whose primary function, in the presence of hydrogen peroxide, is to catalyse the oxidation of thiocynates, leading to the generation of intermediate compounds with a wide range of antimicrobial activities (Fox and Kelly 2006a). Hahn et al. (1998) reported that the concentration of LPO in colostrum is 13 to $30 \mathrm{mg} . \mathrm{L}^{-1}$, compared to $11-45 \mathrm{mg} . \mathrm{L}^{-1}$ in milk. Korohnen (1977) observed that the concentration of LPO in colostrum is low initially but increases rapidly to reach a maximum after 3-5 days post-partum, followed by a slow decrease until a plateau is reached after about 2 weeks. Catalase activity is also higher in colostrum than in milk and decreases throughout lactation (Farkye 2002).

\subsubsection{Proteinases}

Plasmin, a serine protease derived from plasminogen, is the principal indigenous proteinase in milk (Fox and Kelly 2006a, b). Dupont et al. (1998) reported that the concentration of plasmin in colostrum is about 10 times higher than that in milk while Madsen et al. (2004) observed a 2-fold greater plasmin activity in colostrum compared with milk. Pyorala and Kaartinen (1988) found a decrease in plasmin activity during the transition from colostrum to milk. Larsen et al. (2006) reported that the activity of the acid milk protease, cathepsin D, is significantly lower in colostrum than in milk.

\subsubsection{Lipases and esterases}

Lipoprotein lipase (LPL) is the principal indigenous lipase in milk (Olivecrona et al. 1992). Mammary LPL activity increases markedly prior to parturition and remains high throughout lactation (Liesman et al. 1988). Saito and Kim (1995) observed that LPL activity in colostrum is low initially but increases rapidly during the first few days of lactation and, thereafter, remains constant for the remainder of lactation. Anderson (1982) reported LPL activity in colostrum, 45\% of which was associated with the serum phase of the first milking post-partum. This value decreased to $34 \%$ during the first $24 \mathrm{~h}$ following parturition. It should be noted that these figures are not representative of total LPL activity in milk as, in milk, more than $90 \%$ of LPL is associated with the casein micelles (see Fox and McSweeney 1998). In addition to LPL, milk contains several other carboxyl ester hydrolases, collectively referred to as esterases (Deeth and Fitz-Gerald 2006). Marquardt and Forster (1965) reported that the concentration of arylesterase in colostrum is higher than in milk, while the carboxylesterase activity has been reported to be higher in colostrum than in milk (Fitz-Gerald et al. 1981).

\subsubsection{Other enzymes}

Milk contains several phosphatases, the principal ones being alkaline phosphatase and acid phosphatase (Fox and Kelly 2006a, b). The concentration of alkaline phosphatase is very high in colostrum and decreases to a minimum within 1-2 weeks of parturition, before increasing and reaching a constant level after approximately 25 weeks (Shakeel Ur-Rehman and Farkye 2002; Fox and Kelly 2006b). The concentration of acid phosphatase is low in colostrum initially, increases to a maximum over 5-6 days 
post-partum, and then decreases and remains low until the end of lactation (Shakeel urRehman and Farkye 2002). The activity of acid phosphatase in milk is much lower (about 2\%) than that of alkaline phosphatase (Shakeel ur-Rehman and Farkye 2002).

Ribonucleases cleave RNA into smaller components; five ribonucleases, A, B, C, D and II-1, have been detected in milk (Bingham and Zittle 1964). Meyer et al. (1987) reported that colostrum contains 10 to 15 times more ribonuclease II- 1 than milk and three times more total ribonuclease activity. Roman et al. (1990) reported that the concentration of ribonuclease in colostrum is highest in the third milk post-partum, followed by an abrupt decrease in concentration until normal levels were reached 1 month after parturition.

Lysozyme catalyses the cleavage of $\beta 1,4$-linkages between muramic acid and $\mathrm{N}$-acetylglucosamine in bacterial cell walls (Fox and McSweeney 1998). Generally, lysozyme activity is higher in colostrum than in milk (Korohnen 1977; Farkye 2002).

$\gamma$-Glutamyl transferase $(\gamma-\mathrm{GT})$, localised on the outer surface of the alveolar cell membrane, catalyses the transport of amino acids across the membrane into the cell (Baumrucker and Pocius 1978). Vacher and Blum (1993) reported 2.5-fold to 3-fold higher $\gamma$-GT activity in colostrum than in milk, which was confirmed by Hadorn et al. (1997) and Ontsouka et al. (2003).

\subsection{Enzyme inhibitors}

Colostrum and milk contain a number of enzyme inhibitors, the concentrations of which are highest initially and decrease rapidly with time post-partum (Georgiev 2008). It is thought that these inhibitors play an important role in the mechanism of absorption of immune components by the calf, i.e. protecting Igs from proteolytic cleavage (Carlson et al. 1980). Christensen et al. (1995) reported the presence of seven plasma-derived protease inhibitors in colostrum, i.e. $\alpha 2$-macroglobulin, $\alpha 2$-antiplasmin, antithrombin III, C1-inhibitor, inter- $\alpha$-trypsin inhibitor, bovine plasma elastase inhibitor and bovine plasma trypsin inhibitor. The concentration of these inhibitors was highest in colostrum initially and decreased dramatically during the first 3 days post-partum, at which point stable levels were reached (Christensen et al. 1995).

Several authors have reported the presence of trypsin inhibitors in colostrum (Cechova et al. 1971; Pineiro et al. 1978), the concentrations of which are nearly 100 times higher than in milk (Honkanen-Buzalski 1981). Quigley et al. (1995) found that colostrum contains approximately $560 \mathrm{mg}$ trypsin inhibitor. $\mathrm{L}^{-1}$ and reported a positive correlation with IgG, in agreement with the study of Pineiro et al. (1978).

Hirado et al. $(1984,1985)$ reported the presence of two types of cysteine protease inhibitors in colostrum, belonging to the kininogen and cystatin subfamilies; Kirihara et al. (1995) purified a third type of cysteine protease inhibitor from colostrum, but information relating to its taxonomy is not available.

The concentration of $\alpha 2$-macroglobulin in colostrum is higher than that in milk (Honkanen-Buzalski and Sandholm 1981); this is a large plasma glycoprotein $(718 \mathrm{kDa})$ with broad-spectrum proteinase inhibitory activity (Barrett et al. 1973). Perez et al. (1989) reported that the first milk post-partum contains the highest concentration of $\alpha 2$-macroglobulin, which decreases very rapidly until a plateau is reached during the second week post-partum. 


\subsection{Nucleotides and nucleosides}

Nucleotides and nucleosides comprise part of the non-protein-nitrogen (NPN) fraction of milk and are present in the sub-milligram range per litre (Schlimme et al. 2000); they have important roles in biochemical synthesis, i.e. nucleic acid synthesis, enhancement of immune response (Schaller et al. 2004), influence the metabolism of fatty acids, contribute to iron absorption in the gut and improve gastrointestinal tract repair after damage (Sanchez-Pozo and Gill 2002).

The concentration of nucleotides in colostrum is higher than in milk (Schlimme et al. 2002). Initially, the concentration of nucleotides in colostrum is very low, but reaches a maximum 24-48 h after parturition, followed by a gradual decrease as lactation continues, up to the third week, when levels stabilise (Gill and Indyk, 2007a). This pattern is seen for nucleoside-5'-monophosphates; 5'-AMP, 5'CMP and 5'UMP, as well as nucleoside-5'-, di- and tri-phosphates, UDP galactose and UDP glucose (Gill and Sanchez-Medina 1981). Generally, the concentrations of nucleotides in milk are one or two orders of magnitude higher than the concentrations of nucleosides (Gill and Sanchez-Medina 1981; Schlimme et al. 1991).

Nucleosides are $\mathrm{N}$-glycosides of pyrimidines and purines (Schlimme et al. 2002). The concentration of nucleosides is higher in colostrum than in milk; however, unlike nucleotides, no distinct maximum is observed during the first 2 days after parturition (Schlimme et al. 1991). The nucleoside concentration decreases during the colostral phase and reaches a constant level approximately 3 weeks post-partum (Schlimme et al. 2000). The levels of pyrimidine nucleosides in milk are higher than for purine nucleosides. The concentration of uridine is relatively high in early colostrum but decreases by approximately two orders of magnitude during the first few hours postpartum, whereas the concentration of cytidine reaches a maximum on the second day of lactation (Gill and Indyk 2007b).

\subsection{Cytokines}

Cytokines are a diverse group of proteins, peptides or glycoproteins which have profound biological effects at minute concentrations (10 to 1000 pg.mL ${ }^{-1}$ ) (Gauthier et al. 2006). These molecules are principally responsible for modulating the immune system (Biswas et al. 2007) and include the interleukins (IL), tumour necrosis factors (TNF) and interferons (INF). Sacerdote et al. (2013) reported the presence of a wide range of cytokines in colostrum, but the concentrations in milk were not measured. Hagiwara et al. (2000) reported that the concentrations of IL-1 $\beta$, IL-6, TNF- $\alpha$, INF- $\gamma$ and IL-1ra are significantly higher in colostrum than in milk. These results are in agreement with those of Goto et al. (1997) and Sobczuk-Szul et al. (2013), who observed higher levels of IL-1 $\beta$, IL- 6 and TNF- $\alpha$ in colostrum compared with milk.

\subsection{Lipids}

The composition and structure of milk fat has been reviewed extensively (MacGibbon and Taylor 2006; Palmquist 2006), but relatively little work has been done on changes in the composition and structure of milk fat during the transition from colostrum to milk. 
Generally, but not always, the fat content of colostrum is higher than that of milk (Parrish et al. 1950; Foley and Otterby 1978; Marnila and Korohnen 2002). Kehoe et al. (2007) and Morrill et al. (2012) reported a very wide range of average fat content of colostrum; Abd El-fattah et al. (2012) reported a decrease in the fat content of colostrum from Holstein cows from $8.04 \%$ at parturition to $3.9 \%$ after 5 days.

In terms of the profile of individual fatty acids, Laakso et al. (1996) reported that during the first week post-partum, the proportions of stearic acid, oleic acid and shortchain fatty acids (C4-C10) in colostrum were low and increased thereafter. Similarly, Palmquist et al. (1993) observed that the proportions of short-chain fatty acids, with the exception of $\mathrm{C} 4$, are low in colostrum, but that these fatty acids increase, reaching $>90 \%$ of maximum levels by 8 weeks of lactation. Laakso et al. (1996) also reported that the relative amounts of $\mathrm{C} 12-\mathrm{C} 16$ in colostrum, in particular myristic and palmitic acids, were high initially and decreased with time post-partum. Several authors have reported that colostrum contains high levels of C18:0 and C18:1 (Lynch et al. 1992; Palmquist et al. 1993). High levels of long-chain fatty acids are present in colostrum because, at parturition, cows are in a negative energy balance, resulting in the mobilisation of adipose tissue fatty acids which are incorporated into milk fat (Belyea and Adams 1990). Concomitantly, high levels of long-chain fatty acids inhibit de novo synthesis of short-chain fatty acids (Bauman and Davis 1974). Laakso et al. (1996) observed changes in the TAG distribution during the colostral period, i.e. the proportion of molecules with an acyl carbon number (ACN) 38-40 increased and those with ACN 44-48 decreased. Paszczyk et al. (2005) reported that colostrum contains a lower content of trans fatty acids and cis-9 trans-11 C18:2 (CLA) than milk.

Bitman and Wood (1990) reported that all five major subclasses of phospholipids are present at significantly lower concentrations in colostrum than in milk and that the total phospholipid content of milk increases from the third to seventh day of lactation.

Sterols are minor components of milk lipids, at approximately $0.3 \%$ of total lipids, of which cholesterol accounts for approximately 95\% (MacGibbon and Taylor 2006). Small amounts of other sterols have been identified in milk, namely campesterol, stigmasterol and $\beta$-sitosterol (Minicione et al. 1977). Precht (2001) observed that the cholesterol content of colostrum is significantly higher than that of milk, i.e. 327 and $285 \mathrm{mg} .100 \mathrm{~g}^{-1}$ fat, respectively.

\subsection{Minerals}

The mineral components, or milk salts, include citrates, phosphates and chlorides of $\mathrm{H}^{+}, \mathrm{K}^{+}, \mathrm{Na}^{+}, \mathrm{Mg}^{2+}$ and $\mathrm{Ca}^{2+}$, which are present either as ions in solution or as colloidal species complexed with the caseins (Lucey and Horne 2009).

Milk is saturated with respect to calcium and phosphate ions, which exist in a dynamic equilibrium between serum and colloidal forms (Lucey and Horne 2009). Several authors have reported high concentrations of calcium and phosphate in colostrum; Tsioulpas et al. (2007) reported that the concentrations of calcium and phosphate decreased from 2168 and $1635 \mathrm{mg} \cdot \mathrm{kg}^{-1}$, respectively, at parturition, to 1342 and 929 mg. $\mathrm{kg}^{-1}$, respectively, after 15 days. A similar trend was observed by Jeong et al. (2009). Abd El-Fattah et al. (2012) observed a similar trend for the calcium concentration during the transition from colostrum to milk, but the concentration of phosphate in colostrum and milk was significantly lower than that reported in previous 
studies. On the other hand, Kehoe et al. (2007) reported mean concentrations of calcium and phosphate in colostrum which were approximately 4-fold and 5-fold higher than the concentrations found in milk. White and Davies (1958a) reported that the average concentrations of colloidal inorganic calcium and colloidal phosphate were lower in colostrum than in milk. CCP is associated predominantly with casein and is present at higher concentrations in colostrum than in milk (Cerbulis and Farrell 1975). However, during the colostral period, casein micelles are not as mineralised as later in lactation, and so the concentrations of colloidal calcium and colloidal phosphate are not as high as expected.

Several authors have reported increased concentrations of magnesium and sodium in colostrum (Jeong et al. 2009; Tsioulpas et al. 2007; Abd El-Fattah et al. 2012). Unlike for calcium, phosphate, magnesium and sodium, there are variable reports in the literature regarding the concentration of potassium in colostrum. Toshiyoshi et al. (1982) and Klimes et al. (1986) reported low levels of potassium in colostrum at parturition but a gradual increase thereafter. Abd El-Fattah et al. (2012) reported that the concentration of potassium in colostrum decreased from $1795 \mathrm{mg} \cdot \mathrm{kg}^{-1}$ at parturition to $650 \mathrm{mg} \cdot \mathrm{kg}^{-1}$ after 14 days, which is significantly lower than that typically found in milk. No particular trends were observed for potassium concentration by Ontsouka et al. (2003), Tsioulpas et al. (2007) and Jeong et al. (2009). Kehoe et al. (2007) reported that the concentration of potassium in colostrum ranges from 983 to $5511 \mathrm{mg} \cdot \mathrm{kg}^{-1}$, with a mean value of $2845 \mathrm{mg} \cdot \mathrm{kg}^{-1}$, which is significantly higher than other reports in the literature. The precise reason for variations in the level of potassium in colostrum is unknown, but may be related to the nutritional status of the animal and environmental and genetic factors (Cashman 2002).

In addition to the macro-elements mentioned above, approximately 20 other elements are found in milk in trace amounts, including copper, iron, zinc and manganese; relatively little work has been done on their concentrations in colostrum and milk during the early post-partum period. Kehoe et al. (2007) reported that the average concentrations of copper, iron, zinc and manganese in colostrum were 1.7-, 10.7-, 10.9and 3.3-fold higher than values for normal milk. Jeong et al. (2009) observed no particular trends for the concentrations of copper and iron in colostrum over the first $108 \mathrm{~h}$ post-partum; the concentration of zinc was highest in the first milking, but decreased sharply thereafter, while no manganese was detected in colostrum. Abd ElFattah et al. (2012) reported a general decrease in the levels of copper, iron and zinc in colostrum over the first $336 \mathrm{~h}$ post-partum. The concentration of copper fluctuated during the first $24 \mathrm{~h}$, but then decreased gradually; similarly, the concentrations of iron and zinc decreased post-partum.

\subsection{Vitamins}

\subsubsection{Fat-soluble vitamins}

Vitamin A is present in milk in a variety of forms including retinol, retinal, retinoic acid, retinyl esters as well as provitamin A carotenoids such as $\beta$-carotene (Morrissey and Hill 2009). Several authors have reported increased concentrations of vitamin A in colostrum (Jensen et al. 1999; Debier et al. 2005); the concentrations of vitamin A and carotenoids decrease drastically during the first few days of lactation and stabilise after 
approximately day 5 (Parrish et al. 1948; Calderon et al. 2007; Abd El-fattah et al. 2012).

Vitamin E includes two main groups of compounds: tocopherols ( $\alpha-, \beta-, \gamma-$ and $\delta-)$ and tocotrienols $(\alpha-, \beta-, \gamma-$ and $\delta-)$ (Morrissey and Hill 2009). The transfer of vitamin E into colostrum does not appear to occur via a passive mechanism associated with the transfer of lipids (Debier et al. 2005) but rather by a mechanism involving low-density lipoproteins (Schweigert 1990). The concentration of vitamin E in milk is approximately $90 \mu \mathrm{g} .100 \mathrm{~g}^{-1}$ (Fox and McSweeney 1998), and its concentration in colostrum is much higher (Debier et al. 2005; Calderon et al. 2007). Kehoe et al. (2007) reported that the concentration of vitamin $\mathrm{E}$ in colostrum ranges from 60 to $1040 \mu \mathrm{g} .100 \mathrm{~g}^{-1}$, with a mean value of $292 \mu \mathrm{g} .100 \mathrm{~g}^{-1}$. Parrish et al. (1949) reported that the concentration of vitamin E decreased over the course of the first six milkings post-partum, and Hidiroglou et al. (1995) reported that the concentration of $\alpha$-tocopherol in colostrum decreased from 1.9 to $0.3 \mathrm{mg} . \mathrm{L}^{-1}$ over the first 4 days post-partum. $\gamma$-Tocopherol and $\alpha$-tocotrienol have also been detected in trace amounts in colostrum and milk (Barrefors et al. 1995).

The two major forms of vitamin $\mathrm{D}$ are cholecalciferol (vitamin $\mathrm{D}_{3}$ ), which is synthesised by the skin of the cow on exposure to ultraviolet radiation, and ergocalciferol (vitamin $\mathrm{D}_{2}$ ), which is produced by plants on exposure to UV radiation (Bulgari et al. 2013). Henry and Kon (1937) reported a decrease in the vitamin D

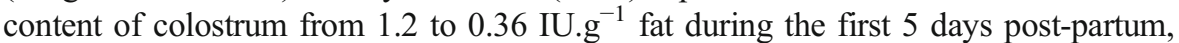
compared with an average vitamin D content of $0.41 \mathrm{IU}_{\mathrm{g}}{ }^{-1}$ fat in milk. Eaton et al. (1947) reported that the concentration of vitamin D in colostrum ranged from 0.83 to 1.81 IU.g ${ }^{-1}$ fat. Yan et al. (1993) also observed a higher concentration of vitamin D in colostrum compared with milk.

Vitamin $\mathrm{K}$ exists in two forms: phylloquinone (vitamin $\mathrm{K}_{1}$ ) and menaquinones (vitamin $\mathrm{K}_{2}$ ) (Morrissey and Hill 2009). Indyk and Woolard (1995) reported that the concentration of phylloquinone was higher in colostrum than in milk, decreasing to normal levels after 5 days of lactation.

\subsubsection{Water-soluble vitamins}

Ascorbic acid (vitamin C) is synthesised in the liver of cows, but calves do not begin to synthesise endogenous vitamin $\mathrm{C}$ until approximately 3 weeks of age and so are reliant on vitamin C from milk during this period (Palludan and Wegger 1984). The vitamin C content of milk ranges from 1.65 to $2.75 \mathrm{mg} .100 \mathrm{~g}^{-1}$, with a mean concentration of $2.11 \mathrm{mg} .100 \mathrm{~g}^{-1}$ (Walstra and Jenness 1984). Kon and Watson (1937) reported that the concentration of vitamin $\mathrm{C}$ in colostrum is slightly higher than that in milk.

The B group vitamins are thiamin, riboflavin, niacin, biotin, pantothenic acid, folate, pyridoxine (and related substances, such as vitamin $\mathrm{B}_{6}$ ) and cobalamin (and its derivative, vitamin $\mathrm{B}_{12}$ ). The concentration of thiamine, riboflavin, folate, vitamin B6 and B12 are higher in colostrum than in milk, while the levels of pantothenic acid and biotin are lower in colostrum and that of niacin is approximately the same as in milk (Marnila and Korohnen 2002). Kehoe et al. (2007) reported that the concentration of thiamin and riboflavin in colostrum ranges from 0.3 to $2.1 \mu \mathrm{g} . \mathrm{mL}^{-1}$ and 2.4 to $9.2 \mu \mathrm{g} . \mathrm{mL}^{-1}$, respectively, with mean values of 0.9 and $4.5 \mu \mathrm{g} \cdot \mathrm{mL}^{-1}$. Sutton et al. (1947) reported that the concentration of riboflavin in 
colostrum was 3.3-fold higher than in milk, with values decreasing sharply between the first and second milking, followed by a more gradual decrease from the second to tenth milking. Pearson and Darnell (1946) also reported that the concentration of pantothenic acid increased during the transition from colostrum to milk, while the niacin content of colostrum was approximately the same as in milk. In contrast, Kehoe et al. (2007) reported that the concentration of niacin was lower in colostrum than in milk. The level of biotin in milk ranges from 21 to $43 \mathrm{ng} \cdot \mathrm{mL}^{-1}$ (Higuchi et al. 2003). Hirano et al. (1991) reported that the biotin content in colostrum was low initially $\left(5.1 \mathrm{ng} . \mathrm{mL}^{-1}\right)$ but increased with the progression of lactation, which is in agreement with the findings of Indyk et al. (2014).

Milk contains $<1 \mu \mathrm{g} .100 \mathrm{~g}^{-1}$ cobalamin and its concentration is fairly constant throughout lactation, except during the colostral period during which it is very high (Nohr and Biesalski 2009). Kehoe et al. (2007) reported that the concentration of pyridoxine in colostrum is lower than the level found in milk. Collins et al. (1951) reported that the concentration of folic acid in colostrum decreases abruptly during the $24 \mathrm{~h}$ after parturition, after which a plateau was reached.

\section{Physical properties of colostrum}

\section{1 pH and buffering capacity}

The $\mathrm{pH}$ of colostrum is lower than that of normal mid-lactation milk (McCarthy and Singh 2009); McIntyre et al. (1952) reported that the $\mathrm{pH}$ of colostrum at parturition ranged from 6.0 to 6.61, with an average value of 6.32, and this value increased with time and reached $\mathrm{pH} 6.5$ after 2 weeks. Several authors have reported similar trends, i.e. that the $\mathrm{pH}$ of colostrum is low initially and increases with time post-partum (Klimes et al. 1986; Madsen et al. 2004; Tsioulpas et al. 2007; Jeong et al. 2009). The precise reason for the low $\mathrm{pH}$ of colostrum is unknown. During the pre-partum period, there is increased permeability of the mammary gland membranes and thus more blood constituents gain access to the milk. Given that colostrum contains significantly more blood components than milk, a $\mathrm{pH}$ closer to that of blood ( $\mathrm{pH} 7.35$ to 7.45) would be expected. Sebela and Klicnik (1977) reported that the low $\mathrm{pH}$ of colostrum is caused by the increased concentration of protein, dihydrogen phosphate, citrate and carbon dioxide.

The buffering capacity of milk is defined as the resistance to changes in $\mathrm{pH}$ on addition of acid or base; the principal buffering components of milk are soluble phosphate, colloidal calcium phosphate, citrate, carbonate and proteins (Lucey et al. 1993). McIntyre et al. (1952) reported that the buffering capacity of colostrum was greater than that of milk and decreased rapidly during the first four milkings. Klimes et al. (1986) also reported a markedly higher buffering capacity of colostrum compared with mature milk. Klimes et al. (1986) reported that the titratable acidity of colostrum is approximately 2 to 2.5 times higher than that of milk (see also Tsioulpas et al. 2007; Jeong et al. 2009). Tsioulpas et al. (2007) observed a logarithmic relationship between titratable acidity and the total protein level of colostrum, while Nardone et al. (1997) also observed a higher titratable acidity for colostrum than milk and reported a positive correlation with protein content. 


\subsection{Colour}

Colostrum has a reddish-yellow colour, due largely to the presence of carotenoids (Edelsten 1988). It has been observed that levels of carotenoids are high in the initial colostrum, in particular the fat fraction, but decrease rapidly as the mammary secretions change to normal milk (Parrish et al. 1948). Calderon et al. (2007) reported that the concentration of the carotenoids lutein, all-trans $\beta$-carotene and cis-13 $\beta$-carotene in colostrum were highest initially and decreased sharply during the first week of lactation. The same authors reported a linear relationship between the concentration of $\beta$-carotene and the colour index, and concluded that $\beta$-carotene accounted for $65 \%$ of variations in the colour index in colostrum. Kehoe et al. (2007) reported that the concentration of $\beta$-carotene in colostrum ranges from 0.1 to $3.4 \mu \mathrm{g} . \mathrm{g}^{-1}$, with an average value of $0.68 \mu \mathrm{g} \cdot \mathrm{g}^{-1}$. This is significantly higher than the average concentration of $\beta$-carotene in milk, i.e. $0.2 \mu \mathrm{g} . \mathrm{g}^{-1}$.

The reddish colour of colostrum is due to the presence of red blood cells. During the pre-partum period, there is increased permeability of the mammary gland membranes, and more blood constituents gain access to the milk. A reddish colour in colostrum may also be indicative of mastitic infection (De Olives et al. 2013). Linzell and Peaker (1975) reported that as little as $0.1 \mathrm{~mL}$ blood. $\mathrm{L}^{-1}$ can be detected visually and that $0.4 \mathrm{~mL} . \mathrm{L}^{-1}$ turns milk very pink. Using the CIE LAB colour space, Madsen et al. (2004) reported that the colour of colostrum changed with time after calving; it became lighter (lightness, L, increased over the first six milkings), less red (redness, a, decreased and stabilised after the second milking) and less yellow (yellowness, b, decreased over the first 12 milkings). The same authors reported that the presence of blood in colostrum significantly affected its colour, causing the sample to be darker, less yellow and more red. These results are in agreement with the study of Espada and Vijverberg (2002), who reported that colostrum has a lower CIE LAB b value than milk.

\subsection{Density and specific gravity}

Madsen et al. (2004) reported that the density of colostrum decreased rapidly from 1048 to $1034 \mathrm{~kg} \cdot \mathrm{m}^{-3}$ during the first 2 days post-partum, followed by a more gradual decrease to $1030 \mathrm{~kg} \cdot \mathrm{m}^{-3}$ by 6 days post-partum. Strekozov et al. (2008) observed variations in the density of colostrum according to parity and season of calving. On average, the density of colostrum from first-calf heifers was $1059 \mathrm{~kg} \cdot \mathrm{m}^{-3}$, compared with $1068 \mathrm{~kg} \cdot \mathrm{m}^{-3}$ for third- and fourth-calf cows. Within these groups, the density of colostrum from cows which calved in fall was highest, followed by winter and then spring.

The specific gravity of whole milk at $15.5^{\circ} \mathrm{C}$ ranges from 1.030 to 1.035 , with a mean value of 1.032 (Jenness and Patton 1959). Parrish et al. (1950) reported that the specific gravity of colostrum is highest initially, decreases rapidly between the first and fourth milkings and continues to decrease after the fourth milking, but at a slower rate. The same authors observed that the lowest specific gravity is usually found in secretions from Holstein cows, while marked variations were found for milk for Ayrshire, Jersey and Guernsey cows. Quigley et al. (1994) reported that the specific gravity of colostrum is in the range 1.028 to 1.074 , with a mean value of 1.052 . The same authors reported a positive correlation between specific gravity and total $\mathrm{N}$ and 
protein N. Jeong et al. (2009) observed a similar trend to that seen by Parrish et al. (1950), i.e. the specific gravity of colostrum decreases rapidly between the first and fourth milking from 1.055 to 1.034 and continued to decrease thereafter, but at a less rapid rate. Similarly, Kertz (2008) reported that the specific gravity of colostrum decreases from 1.056 to 1.033 during the first five milkings post-partum. As with colour, it should be noted that, in addition to stage of lactation, the specific gravity of colostrum may also be influenced by SCC (Geer and Barbano 2014).

\subsection{Osmotic pressure}

The osmotic pressure of milk is a colligative property which is closely related to its freezing and boiling points. Natural variations in the osmotic pressure of milk (and hence freezing point) are limited by the physiology of the mammary gland and so remains relatively constant (Fox and McSweeney 1998). Very little work has been reported on the osmotic pressure of colostrum. McIntyre et al. (1952) reported that the average osmotic pressure of colostrum decreased rapidly in the first four milkings postpartum and that only relatively small changes were noted thereafter; the osmotic pressure at the 28th milking was about two thirds of that of the initial colostrum; this high osmotic pressure was attributed to a high mineral content. Ontsouka et al. (2003) found no significant difference between the osmolarity of colostrum on day 2 and that of mature milk.

\subsection{Properties of casein micelles}

Brooker and Holt (1978) reported that colostrum contains casein micelles several micrometres in diameter, suggesting that they were formed by aggregation of particles comparable in size to normal casein micelles. Walstra et al. (2006) reported that colostrum and early-lactation milk contain a small number of very large micelles, reaching diameters of $600 \mathrm{~nm}$. According to Tsioulpas et al. (2007) the average diameter of casein micelles was almost constant throughout the first 90 days of lactation, except for the transition from day 1 to 2 , during which it decreased from 227 to $189 \mathrm{~nm}$. The same authors attributed the increased size of casein micelles in colostrum to the high protein (casein) and $\mathrm{Ca}$ (especially $\mathrm{Ca}^{2+}$ ) concentrations.

The relative proportions of the individual caseins in the micelles vary with micelle size. Proportions of $\alpha_{s^{-}}$and $\beta$-casein decrease with decreasing micelle size, while that of $\kappa$-casein increases (Donnelly et al. 1983). The relative proportion of glycosylated к-casein is inversely related to micelle size (Zbikowska et al. 1992). Kroeker et al. (1985) reported that, in terms of the relative percentage of casein, the percentage of $\alpha_{\mathrm{s}}$-casein in colostrum fell initially after parturition and remained constant thereafter. The same authors observed that the relative percentage of $\beta$-casein was low initially and increased during the first 2 months of lactation, while the relative percentage of $к$-casein was unaffected by the stage of lactation. Sobczuk-Szul et al. (2013), who investigated the relative percentage of individual caseins in colostrum over the first eight milkings post-partum, reported that the relative percentage of $\alpha_{\mathrm{s}}$-casein increased, the relative percentage of $\beta$-casein remained stable and the relative percentage of к-casein decreased over time after calving. 


\subsection{Ethanol stability}

Ethanol stability is defined as the minimum concentration of added aqueous ethanol that causes milk coagulation (Horne and Parker 1979). Serum phase components, in particular ionic calcium, govern the sigmoidal shape and position of the ethanol stability/pH profile (Horne and Parker 1981a, b). Other factors which influence the ethanol stability of milk include salts (calcium, magnesium, phosphate and citrate) (Donnelly and Horne 1986), ionic strength (Horne 1987) and pH (Horne 1992). Tsioulpas et al. (2007) found that the ethanol stability of colostrum was low for the first 4 days following parturition (54\% on average) and only reached $70 \%$ by day 5 ; samples which had poor ethanol stability also had low $\mathrm{pH}$ and a high ionic calcium concentration.

\subsection{Rennet coagulation properties}

Sebela and Klicnik (1975) observed a shorter rennet coagulation time (RCT) for colostrum than for milk with the lowest RCT on day 3 following parturition. A similar trend was reported by Klimes et al. (1986), while Kvapilik et al. (1975) found that the RCT of colostrum from days 2 to 7 was shorter than on subsequent days. Madsen et al. (2004) observed a decrease in the RCT of colostrum during the first six milkings, followed by an increase at a slower rate. However, curd firmness increased during the first six milkings and then decreased. With the exception of the first six milkings, Madsen et al. (2004) attributed changes in RCT primarily to changes in $\mathrm{pH}$ and casein content. Tsioulpas et al. (2007) reported that the RCT of colostrum was high on day 1 , decreased sharply on day 2 , remained constant for the next 3 days and then increased steadily for the remainder of the study ( 90 days). The high RCT on day 1 could not be explained, as the colostrum had a low $\mathrm{pH}$ and high protein content. A possible explanation proposed by Tsioulpas et al. (2007) was a delay in the enzymatic phase of coagulation as a result of the high protein to chymosin ratio.

\subsection{Somatic cell count}

Several authors have reported that the somatic cell count (SCC) of colostrum is much higher than that of milk (Hallberg et al. 1995; Andrew 2001). In most cases, a high SCC in colostrum is not due to a mastitic infection but is a physiological feature and is most likely due to penetration of cells through leaky tight junctions between the mammary epithelial cells (Nguyen and Neville 1998). Miller et al. (1991) reported that the SCC was highest during the first 2 weeks after calving, with smaller changes thereafter; Bodoh et al. (1976) also reported elevated SCC in early lactation. Ontsouka et al. (2003) reported that the mean SCC of colostrum on day 2 was $1,479,000$ cells. $\mathrm{mL}^{-1}$ compared with 274,000 cells. $\mathrm{mL}^{-1}$ in milk. Madsen et al. (2004) found that the SCC of colostrum decreased from approximately $1,000,000$ cells. $\mathrm{mL}^{-1}$ for milkings 1 and 2 to $<100,000$ at milking 12 . Jeong et al. (2009) reported that the SCC of colostrum was highest initially and decreased gradually over the first $132 \mathrm{~h}$ after parturition. There have been no reports on the changes in individual populations of leucocyte types in colostrum. 


\section{Thermal processing of colostrum}

Heat treatment of milk and dairy products is aimed mainly at killing microorganisms and inactivating enzymes. Pathogens that may be transmitted to dairy calves in colostrum include Mycobacterium avium subsp. paratuberculosis, Salmonella spp., Mycoplasma spp., Listeria monocytogenes, Campylobacter spp., Mycobacterium bovis and Escherichia coli (Elizondo-Salazar and Heinrichs 2008). One strategy to prevent the transmission of infectious diseases to calves is heat treatment of colostrum. However, pasteurisation of colostrum using the same time temperature combinations as used for milk reduces native Ig concentration and increases viscosity.

Meylan et al. (1996) reported that batch pasteurisation $\left(63{ }^{\circ} \mathrm{C}\right.$ for $\left.30 \mathrm{~min}\right)$ of colostrum resulted in a mean loss of native Ig of $12.3 \pm 8.7 \%$. In a similar study, Godden et al. (2003) reported that batch pasteurisation reduced native IgG concentration by 58.5 and $23.6 \%$ for $95-\mathrm{L}$ and $57-\mathrm{L}$ batches, respectively. The same authors observed that the consistency of colostrum was mildly thickened following pasteurisation. McMartin et al. (2006) found that heating colostrum to $63{ }^{\circ} \mathrm{C}$ for 120 min resulted in an estimated $34 \%$ decrease in native IgG concentration and a $33 \%$ increase in viscosity. The same authors reported no differences in native $\operatorname{IgG}$ concentration and viscosity after heating colostrum to $60^{\circ} \mathrm{C}$ for $120 \mathrm{~min}$ and, in doing so, identified the critical temperature at or below which heating would produce no significant changes in native $\mathrm{IgG}$ concentration and viscosity.

Godden et al. (2006) reported that heating of colostrum to $60{ }^{\circ} \mathrm{C}$ for 120 min was sufficient to reduce the level of viable Mycoplasma bovis, Listeria monocytogenes, Escherichia coli O157:H7, Salmonella enteritidis and Mycobacterium avium subspecies paratuberculosis below detectable limits. Similarly, Donahue et al. (2012) found that heating colostrum at $60{ }^{\circ} \mathrm{C}$ for 60 min decreased total plate counts and coliform counts, and did not affect native IgG concentration. Johnson et al. (2007) described increased efficiency of IgG absorption and, consequently, higher serum IgG concentration in calves fed heat-treated $\left(60^{\circ} \mathrm{C}\right.$ for $\left.60 \mathrm{~min}\right)$ compared to raw colostrum. These results are consistent with those of Godden et al. (2012) who, in addition, reported that calves fed heat-treated $\left(60^{\circ} \mathrm{C}\right.$ for $\left.60 \mathrm{~min}\right)$ colostrum were at significantly lower risk for treatment of any illness in the preweaning period compared with calves fed unheated colostrum. The precise reason for this remains unclear, but it was hypothesised that the presence of bacteria in colostrum could interfere with systemic absorption of Ig molecules in the small intestine. Green et al. (2003), using HTST (high-temperature short-time, $72{ }^{\circ} \mathrm{C}$ for $15 \mathrm{~s}$ ) pasteurisation of colostrum, reported an average $28.4 \%$ loss of native $\mathrm{IgG}$, and that all samples congealed into a thick, pudding-like consistency during or immediately after pasteurisation. These results are in agreement with those of Stabel et al. (2004), who reported a $25 \%$ reduction in native IgG concentration and gelling of the colostrum after HTST pasteurisation.

\section{Conclusions}

The composition of colostrum differs markedly from milk, reflecting a difference in the biological function of the two secretions. In addition, the physical and physicochemical properties of colostrum are substantially different from those of mature milk, and, given 
increasing interest in colostrum either as a health-promoting product or a source of fractions with such properties, these properties are of considerable interest. This review has collected published knowledge on these properties in a manner which has not previously been available.

\section{References}

Abd El-Fattah AM, Abd Rabo FHR, El-Dieb SM, El-Kashef HA (2012) Changes in composition of colostrum of Egyptian buffaloes and Holstein cows. BMC Vet Res 8:19

Akita EM, Li-Chan ECY (1998) Isolation of bovine immunoglobulin G subclasses from milk, colostrum, and whey using immobilised egg yolk antibodies. J Dairy Sci 81:54-63

Anderson M (1982) Factors affecting the distribution of lipoprotein lipase activity between serum and casein micelles in bovine milk. J Dairy Res 49:51-59

Andrew SM (2001) Effect of composition of colostrum and transition milk from Holstein heifers on specific rates of antibiotic residue tests. J Dairy Sci 84:100-106

Barile D, Marotta M, Chu C, Mehra R, Grimm R, Lebrilla CB, German JB (2010) Neutral and acidic oligosaccharides in Holstein-Friesian colostrum during the first 3 days of lactation measured by high performance liquid chromatography on a microfluidic chip and time-of-flight-mass spectrometry. J Dairy Sci 93:3940-3949

Barrefors P, Granelli K, Appelqvist LA, Bjoerck L (1995) Chemical characterization of raw milk samples with and without oxidative off-flavor. J Dairy Sci 78:2691-2699

Barrett AJ, Starkey PM (1973) Isolation and characterization of alpha 2-macroglobulin from mastitis milk. J Biochem 133:709-724

Bastian SE, Dunbar AJ, Priebe IK, Owens PC, Goddard C (2001) Measurement of betacellulin levels in bovine serum, colostrum and milk. J Endocrinol 168:203-212

Bauman DE, Davis CL (1974) Biosynthesis of milk fat. In: Larson BL, Smith VR (eds) Lactation-a comprehensive treatise. Academic Press, New York

Baumrucker CR, Pocius PA (1978) Gamma-glutamyltranspeptidase in lactating mammary secretory tissue of cow and rats. J Dairy Sci 61:309-314

Belford DA, Rogers ML, Francis GL, Payne C, Ballard FJ, Goddard C (1997) Platelet-derived growth factor, insulin-like growth factors, fibroblast growth factors and transforming growth factor beta do not account for the cell growth activity present in bovine milk. J Endocrinol 154:45-55

Belyea RL, Adams MW (1990) Energy and nitrogen utilisation of high versus low producing dairy cows. J Dairy Sci 73:1023-1030

Bingham EW, Zittle CA (1964) Ribonuclease in bovine milk: purification and properties. Arch Biochem Biophys 106:235-239

Biswas P, Vecchi A, Mantegani P, Mantelli B, Fortis C, Lazzarin A (2007) Immunomodulatory effects of bovine colostrum in human peripheral blood mononuclear cells. New Microbiol 30:447-454

Bitman J, Wood DL (1990) Changes in milk fat phospholipids during lactation. J Dairy Sci 73:1208-1216

Bleck GT, Wheeler MB, Hansen LB, Chester-Jones H, Miller DJ (2009) Lactose synthase components in milk: concentration of alpha-lactalbumin and beta 1,4-galactotransferase in milk of cows from several breeds at various stages of lactation. Reprod Domest Anim 44:241-247

Blum JW, Hammon HM (2000a) Colostrum - more than just an imunoglobulin supplier. Schweiz Arch Tierh $142: 221-228$

Blum JW, Hammon HM (2000b) Colostrum effects on the gastrointestinal tract, and on nutritional, endocrine and metabolic parameters on neonatal calves. Livest Prod Sci 66:151-159

Bodoh GW, Battista WJ, Schultz LH, Johnston RP (1976) Variation in somatic cell counts in dairy herd improvement milk samples. J Dairy Sci 59:1119-1123

Brooker BE, Holt C (1978) Natural variations in the average size of bovine casein micelles: III. Studies on colostrum by electron microscopy and light scattering. J Dairy Res 45:355-362

Buhler C, Hamman H, Rossi GL, Blum JW (1998) Small intestinal morphology in eight day old calves fed colostrum for different duration or only milk replacer and treated with long-R3-insulin-like growth factorI and growth hormone. J Anim Sci 76:758-765

Bulgari O, Caroli AM, Chessa S, Rizzi R, Gigliotti C (2013) Variation of vitamin D in cow's milk and interaction with beta-lactoglobulin. Molecules 18:10122-10131 
Butler JE (1974) Immunoglobulins of the mammary secretions. In: Larson BL, Smith VL (eds) Lactation-a comprehensive treatise. Academic Press, New York

Calderon F, Chauveau-Duriot B, Martin B, Graulet B, Doreau M, Noziere P (2007) Variations in carotenoids, vitamins $\mathrm{A}$ and $\mathrm{E}$, and colour in cow's plasma and milk during late pregnancy and the first three months of lactation. J Dairy Sci 90:2335-2346

Carlson LTC, Westrom BR, Karlsson BW (1980) Intestinal absorption of proteins by the neonatal piglet fed on sow's colostrum with either natural or experimentally eliminated trypsin-inhibiting activity. Biol Neonate 38:309-320

Cashman KY (2002) Macroelements, nutritional significance. In: Roginski H, Fuquay JW, Fox PF (eds) Encyclopedia of dairy sciences. Elsevier Academic Press, London

Cechova D, Jonakova V, Sorm F (1971) Primary structure of trypsin inhibitor from cow colostrum (component B2). Collect Czech Chem C 36:3342-3357

Cerbulis J, Farrell HM (1975) Composition of milks of dairy cattle. I. Protein, lactose and fat contents and distribution of protein fraction. J Dairy Sci 58:817-827

Cerbulis J, Farrell HM (1976) Composition of the milks of dairy cattle. II. Ash, calcium, magnesium and phosphorus. J Dairy Sci 59:589-593

Cheng JB, Wang JQ, Bu DP, Liu GL, Zhang CG, Wei HY, Zhou LY, Wang JZ (2008) Factors affecting the lactoferrin concentration in bovine milk. J Dairy Sci 91:970-976

Christensen S, Wiegers T, Hermansen J, Sottrup-Jensen L (1995) Plasma-derived protease inhibitors in bovine milk. Int Dairy J 5:439-449

Collier RJ, Miller MA, Hildebrandt JR, Torkelson AR, White TC, Madsen KS, Vicini JL, Eppard PJ, Lanza GM (1991) Factors affecting insulin-like growth factor-I concentration in bovine milk. J Dairy Sci 74: 2905-2911

Collins RA, Harper AE, Schreiber M, Elvehjem CA (1951) The folic acid and vitamin B content of the milk of various species. J Nutr 43:313-321

Cox DA, Burk R (1991) Isolation and characterisation of milk growth factor, a transforming-growth-factorbeta 2-related polypeptide, from bovine milk. Eur J Biochem 197:353-358

D’Amato A, Bachi A, Fasoli E, Boschetti E, Peltre G, Senechal H, Righetti PG (2009) In-depth exploration of cow's whey proteome via combinational peptide ligand libraries. J Proteome Res 8:3925-3936

Davis PF, Greenhill NS, Rowan AM, Schollum LM (2007) The safety of New Zealand bovine colostrum: nutritional and physiological evaluation in rats. Food Chem Toxicol 45:229-236

De Olives AM, Diaz JR, Molina MP, Peris C (2013) Quantification of milk yield and composition changes as affected by subclinical mastitis during the current lactation in sheep. J Dairy Sci 96:7698-7707

Debier C, Pottier J, Goffe CH, Larondelle Y (2005) Present knowledge and unexpected behaviours of vitamins A and E in colostrum and milk. Livest Prod Sci 98:135-147

Deeth HC, Fitz-Gerald CH (2006) Lipolytic enzymes and hydrolytic rancidity. In: Fox PF, McSweeney PLH (eds) Advanced dairy chemistry, volume 2: lipids, 3rd edn. Springer, New York

Donahue M, Godden SM, Bey R, Wells S, Oakes JM, Sreevatsan S, Stabel J, Fetrow J (2012) Heat treatment of colostrum on commercial dairy farms decreases colostrum microbial counts while maintaining colostrum immunoglobulin G concentrations. J Dairy Sci 95:2697-2702

Donnelly WJ, Horne DS (1986) Relationship between ethanol stability of bovine milk and natural variations in milk composition. J Dairy Res 53:23-33

Donnelly WJ, Horne DS, Barry J (1983) Casein compositional studies. III. Changes in Irish milk for manufacturing and the role of milk proteinase. J Dairy Res 50:433-441

Dupont D, Remond R, Collin J (1998) ELISA determination of plasmin and plasminogen in milk of individual cows managed without the dry period. Milchwissenschaft 53:62-69

Eaton H, Spielman AA, Loosli JK, Thomas JW, Norton CL, Turk KL (1947) The placenta transfer and colostral storage of vitamin D in the bovine. J Dairy Sci 30:787-794

Edelsten D (1988) Composition of milk. In: Cross HR, Overby JA (eds) Meat science, milk science and technology. Elsevier Science Publishers B.V, Amsterdam

Elfstrand L, Lindmark-Mansson H, Paulsson M, Nyberg L, Akesson B (2002) Immunoglobulins, growth factors and growth hormone in bovine colostrum and the effects of processing. Int Dairy J 12:879-887

Elizondo-Salazar JA, Heinrichs AJ (2008) Review: heat treating bovine colostrum. Prof Anim Sci 24:530-538

Espada E, Vijverberg H (2002) Milk colour analysis as a tool for the detection of abnormal milk. First North American Conference on Robot Milking, Toronto, Canada, pp 29-38

Evans TW (2002) Review article: Albumin as a drug-biological effects of albumin unrelated to oncotic pressure. Aliment Pharmacol Ther 16:6-11

Farkye NY (2002) Other enzymes. In: Roginski H, Fuquay JW, Fox PF (eds) Encyclopedia of dairy sciences. Elsevier Academic Press, London 
Farrell HM, Jimenez-Flores R, Bleck GT, Brown EM, Butler JE, Creamer LK, Hicks LK, Hollar CM, NgKwai-Hang KF, Swaisgood HE (2004) Nomenclature of the proteins of cow's milk — sixth revision. J Dairy Sci 87:1641-1674

Fitz-Gerald CH, Deeth HC, Kitchen BJ (1981) The relationship between the levels of free fatty acids, lipoprotein lipase, carboxylesterase, $\mathrm{N}$-acetyl- $\beta$-D-glucosaminidase, somatic cell count and other mastitis indices in bovine milk. J Dairy Res 48:253-265

Foley JA, Otterby DE (1978) Availability, storage, treatment, composition, and feeding value of surplus colostrum. J Dairy Sci 61:1033-1060

Fox PF, Kelly AL (2003) Developments in the chemistry and technology of milk proteins. 2. Minor milk proteins. Food Aust 55:231-234

Fox PF, Kelly AL (2006a) Indigenous enzymes in milk: overview and historical aspects - part 1. Int Dairy J 16:500-516

Fox PF, Kelly AL (2006b) Indigenous enzymes in milk: overview and historical aspects-part 2. Int Dairy J 16:517-532

Fox PF, McSweeney PLH (1998) Dairy chemistry and biochemistry. Blackie Academic and Professional, London

Fox PF (2009a) Milk: an overview. In: Thompson A, Boland M, Singh H (eds) Milk proteins: from expression to food. Elsevier Academic Press, London

Fox PF (2009b) Lactose: chemistry and properties. In: McSweeney PLH, Fox PF (eds) Advanced dairy chemistry, volume 3: lactose, water, salts and minor constituents. Springer, New York

Fox PF, Olivecrona T, Vilaro S, Olivecrona G, Kelly AL, McSweeney PLH (2003) Indigenous enzymes in milk. In: Fox PF, McSweeney PLH (eds) Advanced dairy chemistry, volume 1: proteins, 3rd edn. Plenum Publishers, New York

Gapper L, Copestake D, Otter D, Indyk H (2007) Analysis of bovine immunoglobulin G in milk, colostrum and dietary supplements: a review. Anal Bioanal Chem 389:93-109

Gauthier SF, Pouliot Y, Maubois JL (2006) Growth factors from bovine milk and colostrum: composition, extraction and biological activities. Lait 86:99-125

Geer SR, Barbano DM (2014) The effect of immunoglobulins and somatic cells on the gravity separation of fat, bacteria and spores in pasteurised whole milk. J Dairy Sci 97:2027-2038

Georgiev P (2008) Differences in chemical composition between cow colostrum and milk. Bul J Vet Med 11: 3-12

Gill A, Sanchez-Medina F (1981) The determination of acid-soluble nucleotides in milk by improving enzymatic methods: a comparison with the anion-exchange chromatography procedure. J Sci Food Agr 32:1123-1131

Gill BD, Indyk HE (2007a) Development and application of a liquid chromatographic method for analysis of nucleotides and nucleosides in milk and infant formulas. Int Dairy J 17:596-605

Gill BD, Indyk HE (2007b) The determination of nucleotides, nucleosides and nucleobases in milks and infant formulas: a review. J AOAC Int 90:1354-1364

Ginjala V, Pakkanen R (1998) Determination of transforming growth factor-beta 1 (TGF-beta 1) and insulinlike growth factor (IGF-1) in colostrum samples. J Immunoassay Immunochem 19:195-207

Godden SM, Smith S, Feirtag JM, Green LR, Wells SJ, Fetrow JP (2003) Effect of on-farm commercial batch pasteurization of colostrum on colostrum and serum immunoglobulin concentrations in dairy calves. $\mathrm{J}$ Dairy Sci 86:1503-1512

Godden SM, Smoelnski DJ, Donahue M, Oakes JM, Bey R, Wells S, Sreevatsan S, Stabel J, Fetrow J (2012) Heat-treated colostrum and reduced morbidity in preweaned dairy calves: results of a randomized trial and examination of mechanisms of effectiveness. J Dairy Sci 95:4029-4040

Godden S, McMartin S, Feirtag J, Stabel J, Bey R, Goyal S, Metzger L, Fetrow J, Wells S, Chester-Jones H (2006) Heat treatment of bovine colostrum. II. Effects of heating duration on pathogen viability and immunoglobulin G. J Dairy Sci 89:3476-3483

Godhia ML, Patel N (2013) Colostrum - its composition, benefits as a nutraceutical: a review. Curr Res Nutr Food Sci 1:37-47

Gopal PK, Gill HS (2000) Oligosaccharides and glycoconjugates in bovine milk and colostrum. British J Nutr 84:69-74

Goto M, Maruyama M, Kitadate K, Kiriswara R, Obata Y, Koiwa M, Iwai H (1997) Detection of interleukin-1 beta in sera and colostrum of dairy cattle and in sera of neonates. J Vet Med 59:437-441

Green L, Godden S, Feirtag J (2003) Effect of batch and high temperature-short time pasteurisation on immunoglobulin G concentrations in colostrum. J Dairy Sci 86:246

Guilloteau P, Le Huerou-Luron I, Chayvialle JA, Toullec R, Zabielski R, Blum JW (1997) Gut regulatory peptides in young cattle and sheep. J Vet Med 44:1-23 
Hadorn U, Hammon H, Bruckmaier RM, Blum JW (1997) Delaying colostrum intake by one day has important effects on metabolic traits and gastrointestinal and metabolic hormones in neonatal calves. $\mathrm{J}$ Nutr 127:2011-2023

Hagiwara K, Kataoka S, Yamanaka H, Kirisawa R, Iwai H (2000) Detection of cytokines in bovine colostrum. Vet Immunol Immunopathol 76:183-190

Hahn R, Schulz PM, Schaupp C, Jungbauer A (1998) Bovine whey fractionation based on cation-exchange chromatography. J Chromatogr A 795:277-287

Hallberg JW, Dame KJ, Chester ST, Miller CC, Fox LK, Pankey JW, Nickerson SC, Weaver LJ (1995) The visual appearance and somatic cell count of mammary secretions collected from primigravid heifers during gestation and early post-partum. J Dairy Sci 78:1629-1636

Henry KM, Kon SK (1937) A note on the vitamin D content of cow's colostrum. J Biochem 31:2199-2201

Hidiroglou M, Ivan M, Batra TR (1995) Concentrations of vitamin C in plasma and milk of dairy cattle. Ann Zootech 44:399-402

Higuchi H, Maeda K, Kawai K, Kuwano A, Kasamatsu M, Nagatha H (2003) Physiological changes in the concentrations of biotin in the serum and milk and in the physical properties of the claw horn in Holstein cows. Vet Res Commun 27:407-413

Hirado M, Niinobe M, Fujii S (1984) Purification and characterisation of a bovine colostrum low molecular weight cysteine proteinase inhibitor. J Biochem 96:51-58

Hirado M, Tsunasawa S, Sakiyama F, Niinobe M, Fujii S (1985) Complete amino acid sequence of bovine colostrum low-Mr cysteine proteinase inhibitor. FEBS Lett 186:41-45

Hirano M, Honma K, Daimatsu T, Hayakawa K, Oizumi J, Zaima K, Kanke Y (1991) The levels of biotin and biotinidase in bovine milk. Anim Sci Technol 62:1048-1054

Holt C, Jenness R (1984) Interrelationships of constituents and partition of salts in milk samples from eight species. Comp Biochem Physiol 77:275-282

Honkanen-Buzalski T, Sandholm M (1981) Trypsin inhibitors in mastitic milk and colostrum: correlation between trypsin-inhibitor capacity, bovine serum albumin and somatic cell counts. J Dairy Res 48:213223

Horne DS, Parker TG (1979) The pH sensitivity of the ethanol stability of individual cow milks. Neth Milk Dairy J 34:126-130

Horne DS, Parker TG (1981a) Factors affecting the ethanol stability of bovine milk. I. Effect of serum phase components. J Dairy Res 48:273-284

Horne DS, Parker TG (1981b) Factors affecting the ethanol stability of bovine milk. II. The origin of the $\mathrm{pH}$ transition. J Dairy Res 48:285-291

Horne DS (1987) Relationship between ethanol stability of bovine and natural variations in milk composition. J Dairy Res 54:389-395

Horne DS (1992) Ethanol stability. In: Fox PF (ed) Advanced dairy chemistry, volume 1, 2nd edn. Elsevier Applied Science, London

Horne DS, Parker TG, Donnelly WJ, Davies DT (1986) Factors affecting the ethanol stability of bovine skim milk. VII. Lactational and compositional effects. J Dairy Res 53:407-417

Iacopetta BJ, Grieu F, Horisberger M, Sunahara GI (1992) Epidermal growth factor in human and bovine milk. Acta Paediatr Scand 81:287-291

Indyk HE, Filonzi EL (2005) Determination of lactoferrin in bovine milk, colostrum and infant formulas by optical biosensor analysis. Int Dairy J 15:429-438

Indyk HE, Woolard DC (1995) The endogenous vitamin K1 content of bovine milk: temporal influence of season and lactation. Food Chem 54:403-407

Indyk HE, Gill BD, Woolard DC (2014) Biotin content of paediatric formula, early lactation milk and seasonal bovine milk powders by biosensor immunoassay. Int Dairy J 35:25-31

Jenness R, Holt C (1987) Casein and lactose concentrations in milk of 31 species are negatively correlated. Experientia 43:1015-1018

Jenness R, Patton S (1959) Principles of dairy chemistry. John Wiley, New York

Jensen SK, Johannsen AKB, Hermansen JE (1999) Quantitative secretion and maximal secretion capacity of retinol, beta-carotene and alpha-tocopherol into cow's milk. J Dairy Res 66:511-522

Jeong SG, Ham JS, Kim DH, Ahn CN, Chae HS, You YM, Jang A, Kwon IK, Lee SG (2009) Physiochemical properties of colostrum by milking time of Gyeonggi Province. Korean J Food Sci Ann 29:445-456

Johnson JL, Godden SM, Molitor T, Ames T, Hagman D (2007) Effects of feeding heat-treated colostrum on passive transfer of immune and nutritional parameters in neonatal dairy calves. J Dairy Sci 90:5189

Kehoe SI, Jayarao BM, Heinrichs AJ (2007) A survey of bovine colostrum composition and colostrum management practices on Pennsylvania farms. J Dairy Sci 90:4108-4116

Kertz A (2008) Composition of bovine colostrum variable. Feedstuffs 80-81 
Kirihara O, Ohishi H (1995) Functional proteins in bovine milk. Jpn J Dairy Food Sci 44:9-17

Kirihara O, Ohishi H, Hosono A (1995) Purification and characterisation of a low molecular mass cysteine proteinase inhibitor from bovine colostrum. Lebensm Wiss Technol 28:495-500

Klimes J, Jagos P, Bouda J, Gajdusek S (1986) Basic qualitative parameters of cow colostrum and their dependence on season and post-partum time. Acta Vet Brno 55:23-39

Kon SK, Watson MB (1937) The vitamin C content of cow's milk. J Biochem 31:223-226

Korohnen H (1977) Antimicrobial factors in bovine colostrum. J Agr Sci Finland 49:434-447

Korohnen H (1998) Colostrum immunoglobulins and the complement system - potential ingredients of functional foods. Bulletin 336, International Dairy Federation, Brussels, pp. 36-40

Korohnen H, Marnila P, Gill HS (2000) Milk immunoglobulins and complement factors. British J Nutr 84:7580

Korohnen H, Syvaoja EL, Ahola-Lutilla H, Sivela S, Kopola S, Husu J, Kosunen TU (1995) Bactericidal effect of bovine normal and immune serum, colostrum and milk against Helicobacter pylori. J Appl Bacteriol 78:655-662

Kroeker EM, Ng Kwai Hang KF, Hayes JF, Moxley LJ (1985) Effects of environmental factors and milk protein polymorphism on composition of casein fraction in bovine milk. J Dairy Sci 68:1752-1757

Kvapilik J, Suchanek B, Brauner J (1975) Conversion of colostrum to milk focussing on its chemical and technological properties. Czech J Anim Sci 20:169-182

Laakso P, Manninen P, Makinen J, Kallio H (1996) Postparturition changes in the triacylglycerols of cow colostrum. Lipids 31:937-943

Larsen LB, McSweeney PLH, Hayes MG, Andersen JB, Ingvartsen KL, Kelly AL (2006) Variation in activity and heterogeneity of bovine milk proteases with stage of lactation and somatic cell count. Int Dairy J 16 : $1-8$

Larson BL (1992) Immunoglobulins of the mammary secretions In: Fox PF (ed) Advanced dairy chemistry, volume 1: proteins. Elsevier Science Publishers, Barking

Le A, Barton LD, Sanders JT, Zhang Q (2011) Exploration of bovine milk proteome in colostral and mature whey using an ion-exchange approach. J Proteome Res 10:692-704

Levieux D, Ollier A (1999) Bovine immunoglobulin G, beta-lactoglobulin, alpha-lactalbumin and serum albumin in colostrum and milk during the early post-partum period. J Dairy Res 66:421-430

Liesman JS, Emery RS, Akers RM, Tucker HA (1988) Mammary lipoprotein lipase in plasma of cows after parturition or prolactin infusion. Lipids 23:504-507

Linzell JL, Peaker M (1975) Efficacy of measurement of the electrical conductivity of milk for the detection of subclinical mastitis in cows: detection of infected cows at a single visit. Brit Vet J 131:447-460

Lucey JA, Horne DS (2009) Milk salts: technological significance. In: Fox PF, McSweeney PLH (eds) Advanced dairy chemistry, volume 3: lactose, water, salts and minor constituents, 3rd edn. Springer, New York

Lucey JA, Hauth B, Gorry C, Fox PF (1993) Acid-base buffering of milk. Milchwissenschaft 48:268-272

Lynch JM, Barbano DM, Bauman DE, Hartnell GF, Nemeth MA (1992) Effect of a prolonged-release formulation of N-methionyl bovine somatotropin (Sometribove) on milk fat. J Dairy Sci 75:1794-1809

MacGibbon AKH, Taylor MW (2006) Composition and structure of bovine milk lipids. In: Fox PF, McSweeney PLH (eds) Advanced dairy chemistry, volume 2: lipids, 3rd edn. Springer, New York, NY

Madsen BD, Rasmussen MD, O’Nielsen M, Wiking L, Larsen LB (2004) Physical properties of mammary secretions in relation to chemical changes during transition from colostrum to milk. J Dairy Res 71:263272

Marnila P, Korohnen H (2002) Colostrum. Encyclopedia of dairy sciences

Marquardt RR, Forster TL (1965) Milk A-esterase levels as influenced by stage of lactation. J Dairy Sci 48: 1526-1528

Martin-Sosa S, Martin MJ, Garcia-Pardo LA, Hueso P (2003) Sialyoligosaccharides in human and bovine milk and in infant formulas: variations with the progression of lactation. J Dairy Sci 86:52-59

McCarthy OJ, Singh K (2009) Physico-chemical properties of milk. In: McSweeney PLH, Fox PF (eds) Advanced dairy chemistry, volume 3: lactose, water, salts and minor constituents, 3rd edn. Springer, New York

McIntyre RT, Parrish DB, Fountaine FC (1952) Properties of the colostrum of the dairy cow. VII. pH, buffering capacity and osmotic pressure. J Dairy Sci 23:405-422

McJarrow P, Van Amelsfort-Schoonbeek J (2004) Bovine sialyl oligosaccharides: seasonal variations in their concentrations in milk, and a comparison of the colostrum of Jersey and Friesian cows. Int Dairy J 14: 571-579 
McMartin S, Godden SM, Metzger L, Feirtag J, Bey R, Stabel J, Goyal S, Fetrow J, Wells S, Chester-Jones H (2006) Heat treatment of bovine colostrum I. Effects of temperature on viscosity and immunoglobulin G level. J Dairy Sci 89:2110-2118

Meyer DH, Kunin AS, Maddalena J, Meyer WL (1987) Ribonuclease activity and isoenzymes in raw and processed cows' milk and infant formulas. J Dairy Sci 70:1797-1803

Meylan M, Rings DM, Shulaw WP, Kowalski JJ, Bech-Nielsen S, Hoffsis F (1996) Survival of Mycobacterium paratubercolosis and preservation of immunoglobulin $\mathrm{G}$ in bovine colostrum under experimental conditions simulating pasteurisation. Am J Vet Res 57:1580-1585

Miller RH, Paape MJ, Fulton LA (1991) Variation in milk somatic cells of heifers at first calving. J Dairy Sci $74: 3782-3790$

Minicione B, Spagna Musso S, De Franciscus G (1977) Studies on the different species. Sterol content of cow's milk. Milchwissenschaft 32:599-603

Moody EG, Wise GH, Parrish DB, Atkeson W (1951) Properties of the colostrum of the dairy cow. VI. Creaming and rate of flow. J Dairy Sci 34:106-115

Moore M, Tyler JW, Chigerwe M, Dawes ME, Middleton JR (2005) Effect of delayed colostrum collection on colostral IgG concentration in dairy cows. J Am Vet Med Assoc 226:1375-1377

Morrill KM, Conrad E, Lago A, Campbell J, Quigley J, Tyler H (2012) Nationwide evaluation of quality and composition of colostrum on dairy farms in the United States. J Dairy Sci 95:3997-4005

Morrissey PA, Hill TR (2009) Fat-soluble vitamins and vitamin C in milk and dairy products. In: Fox PF, McSweeney PLH (eds) Advanced dairy chemistry, volume 3: lactose, water, salts and minor constituents, 3rd edn. Springer, New York

Nakamura T, Kawase H, Kimura K, Watanabe Y, Ohtani M (2003) Concentrations of sialyloligosaccharides in bovine colostrum and milk during the prepartum and early lactation. J Dairy Sci 86:1315-1320

Nardone A, Lacetera N, Bernabucci U, Ronchi B (1997) Composition of colostrum from dairy heifers exposed to high air temperatures during late pregnancy and the early post-partum period. J Dairy Sci 80:838-844

Nguyen DD, Neville MC (1998) Tight junction regulation in the mammary gland. J Mammary Gland Biol 3: 233-246

Ninonuevo MR, Park Y, Hin H, Zhang J, Ward RE, Clowers BH, German JB, Freeman SL, Kileen K, Grimm R, Lebrilla CB (2006) A strategy for annotating the human milk glycome. J Agr Food Chem 54:7471-7480

Nissen A, Bendixen E, Ingvartsen KL, Rontved CM (2012) In-depth analysis of low abundant proteins in bovine colostrum using different fractionation techniques. Proteomics 12:2866-2878

Nissen A, Bendixen E, Ingvartsen KL, Rontved CM (2013) Expanding the bovine milk proteome through extensive fractionation. J Dairy Sci 96:7854-7866

Nohr D, Biesalski HK (2009) Vitamins in milk and dairy products: B-group vitamins. In: Fox PF, McSweeney PLH (eds) Advanced dairy chemistry, volume 3: lactose, water, salts and minor constituents, 3rd edn. Springer, New York

Olivecrona T, Vilaro S, Bengtsson-Olivecrona G (1992) Indigenous enzymes in milk: lipases. In: Fox PF (ed) Advanced dairy chemistry, volume 1: proteins, 2nd edn. Elsevier Applied Science

Ontsouka CE, Bruckmaier RM, Blum JW (2003) Fractionized milk composition during removal of colostrum and mature milk. J Dairy Sci 86:2005-2011

Oyeniyi OO, Hunter AG (1978) Colostral constituents including immunoglobulins in the first three milkings post-partum. J Dairy Sci 61:44-48

Pakkanen R (1998) Determination of transforming growth factor-beta 2 (TGF-beta 2) in bovine colostrum samples. J Immunoassay Immunochem 19:23-37

Pakkanen RJ, Aalto J (1997) Growth factors and antimicrobial factors of bovine colostrum: a review. Int Dairy J 7:285-297

Palludan B, Wegger I (1984) Plasma ascorbic acid in calves. In: Wegger I, Tagwerker FT, Mustgaard J (eds) Proceedings, workshop on ascorbic acid in domestic animals. Royal Danish Agricultural Society, Copenhagen

Palmquist DL (2006) Milk fat: origin of fatty acids and influence of nutritional factors thereon. In: Fox PF, McSweeney PLH (eds) Advanced dairy chemistry, volume 2: lipids, 3rd edn. Springer, New York

Palmquist DL, Beaulieu AD, Barbano DM (1993) Feed and animal factors influencing milk fat composition. J Dairy Sci 76:1753-1771

Parrish DB, Wise GH, Hughes JS (1947) Properties of the colostrum of the dairy cow. I. Tocopherol levels in colostrum and in early milk. J Dairy Sci 30:849-860

Parrish DB, Wise GH, Hughes JS (1948) Properties of the colostrum of the dairy cow. II. Effect of prepartal rations upon nitrogenous constituents. J Dairy Sci 31:889-895

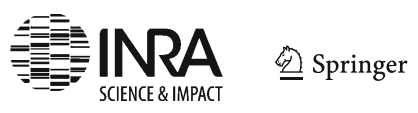


Parrish DB, Wise GH, Hughes JS (1949) Properties of the colostrum of the dairy cow. IV. Effect of form of vitamin A and of tocopherol supplements on concentrations of vitamin A and carotenoids. J Dairy Sci 32: 458-464

Parrish DB, Wise GH, Highes JS, Atkeson FW (1950) Properties of the colostrum of the dairy cow. V. Yield, specific gravity and concentrations of total solids and its various components of colostrum and early milk. J Dairy Sci 33:457-465

Paszczyk B, Zegarska Z, Borejszo Z (2005) The contents of trans fatty acids and CLA in cow colostrum and milk fat in the early lactation period. Czech J Food Sci 23:159-165

Pearson PB, Darnell AL (1946) The thiamine, riboflavin, nicotinic acid and pantothenic acid content of colostrum and milk of the cow and ewe. J Nutr 31:51-57

Perez MD, Sanchez L, Aranda P, Ena JM, Oria R, Calco M (1990) Synthesis and evolution of concentration of $\beta$-lactoglobulin and $\alpha$-lactalbumin from cow and sheep colostrum and milk throughout early lactation. Cell Mol Biol 36:205-212

Perez MD, Sanchez L, Aranda P, Sala FJ, Calvo M (1989) Time-course levels of $\alpha_{2}$-macroglobulin and albumin in cow colostrum and milk and $\alpha_{2}$-macroglobulin levels in mastitic cow milk. Ann Rech Vet 20: 251-258

Pineiro A, Brock JH, Esparza I (1978) Isolation and properties of bovine colostral trypsin inhibitor. Ann Rech Vet 9:281-286

Playford RJ (2001) Peptide therapy and the gastroenterologist: colostrum and milk-derived growth factors. Clin Nutr 20:101-106

Playford RJ, MacDonald CE, Johnson WS (2000) Colostrum and milk-derived peptide growth factors for the treatment of gastrointestinal disorders. Am J Clin Nutr 72:5-14

Precht D (2001) Cholesterol content in European bovine milk fats. Nahrung 45:2-8

Pyorala S, Kaartinen L (1988) Milk plasmin, antitrypsin, N-acetyl-beta-D-glucosaminidase and bacterial growth in lactoserum during the early post-partum period. Acta Paediatr Scand 29:145-150

Quigley JD, Martin KR, Dowlen HH (1995) Concentrations of trypsin inhibitor and immunoglobulins in colostrum from Jersey cows. J Dairy Sci 78:1573-15

Quigley JD, Martin KR, Dowlen HH, Wallis LB, Lamar K (1994) Immunoglobulin concentration, specific gravity, and nitrogen fractions of colostrum from Jersey cattle. J Dairy Sci 77:264-296

Reinhardt TA, Lippolis JD (2006) Bovine milk fat globule membrane proteome. J Dairy Res 73:406-416

Reiter B (1978) Review of the progress of dairy science: antimicrobial systems in milk. J Dairy Res 45:131147

Rodriguez EMR, Alaejos SM, Romero CD (2001) Mineral concentrations in cow's milk from the Canary Islands. J Food Compos Ann 14:419-430

Roman M, Sanchez L, Calvo M (1990) Changes in ribonuclease concentration during lactation in cows' colostrum and milk. Neth Milk Dairy J 44:207-212

Sacerdote P, Mussano F, Franchi S, Panerai AE, Bussolati G, Carossa S, Bartorelli A, Bussolati B (2013) Biological components in a standardized derivative of bovine colostrum. J Dairy Sci 96:1745-1754

Saito Z, Kim GY (1995) Effects of lactation stage on temperature-activated lipolysis and lipase activity in cow's milk. Jpn J Dairy Sci 44:139-145

Sanchez-Pozo A, Gill A (2002) Nucleotides as semiessential nutritional components. British J Nutr 87:135137

Scammell AW (2001) Production and uses of colostrum. Aust J Dairy Technol 56:74-82

Schaller JP, Kuchan MJ, Thomas DL, Cordle CT, Winship TR, Buck RH (2004) Effect of dietary ribonucleotides on infant immune status. Part 1: humoral responses. Pediatr Res 56:883-890

Schams D (1994) Growth factors in milk. Endocr Regul 28:3-8

Schlimme E, Martin D, Tait D (2002) Nucleosides and nucleotides in milk. In: Roginski H, Fuquay JW, Fox PF (eds) Encyclopedia of dairy sciences. Elsevier Academic Press, London

Schlimme E, Maryin D, Meisel H (2000) Nucleosides and nucleotides: natural bioactive substances in milk and colostrum. British J Nutr 84:59-68

Schlimme E, Raezke KP, Ott F (1991) Ribonucleotides as minor milk constituents. Z Ernahrungswissenschaft 30:138-152

Schweigert FJ (1990) Effect of gestation and lactation on lipoprotein pattern and composition of dairy cows. J Anim Physiol Ann 63:75-83

Sebela F, Klicnik V (1975) Properties of cow colostrum 1. Communication: chemical and biological properties. Acta U Agr 23:17-25

Sebela F, Klicnik V (1977) The relationship between milk acidity after milking and cow's age. Czech J Anim Sci 22:161-170 
Shahani KM, Harper WJ, Jensen RG, Parry RM, Zittle CA (1973) Enzymes in bovine milk: a review. J Dairy Sci 56:531-543

Shakeel Ur-Rehman S, Farkye NY (2002) Phosphatases. In: Roginski H, Fuquay JW, Fox PF (eds) Encyclopedia of dairy sciences. Elsevier Academic Press, London, UK

Smolenski G, Haines S, Kwan FYS, Bond J, Farr V, Davis SR, Stelwagen K, Wheeler TT (2007) Characterisation of host defense proteins in milk using a proteomic approach. J Proteome Res 6:207-215

Sobczuk-Szul M, Wielgosz-Groth Z, Wronski M, Rzemieniewski A (2013) Changes in the bioactive protein concentrations in the bovine colostrum of Jersey and Polish Holstein-Friesian cows. Turk J Vet Anim Sci 37:43-49

Stabel JR, Hurd S, Calvente L, Rosenbush RF (2004) Destruction of Mycobacterium paratuberculosis, Salmonella spp., and Mycoplasma spp. in raw milk by a commercial on farm high-temperature, shorttime pasteuriser. J Dairy Sci 87:2177-2183

Stelwagen K, Carpenter E, Haigh B, Hodgkinson A, Wheeler TT (2009) Immune components of bovine colostrum and milk. J Anim Sci 87:3-9

Strekozov NI, Motova EN, Fedorov YN (2008) Evaluation of the chemical composition and immunological properties of colostrum of cow's first milk yield. Russ Agric Sci 34:259-260

Sutton TS, Wagner RG, Kaeser HE (1947) The concentration and output of carotenoid pigments, vitamin A, and riboflavin in the colostrum and milk of dairy cows. J Dairy Sci 30:927-932

Tao N, DePeters EJ, Freeman S, German JB, Grimm R, Lebrilla CB (2008) Bovine milk glycome. J Dairy Sci 91:3768-3778

Tao N, DePeters EJ, German JB, Grimm R, Lebrilla CB (2009) Variations in bovine milk oligosaccharides during early and middle lactation stages analysed by high performance liquid chromatography-chip/mass spectrometry. J Dairy Sci 92:2991-3001

Toshiyoshi T, Ohta S, Ishikawa T (1982) Analysis of changes of properties and compositions from colostrum to normal milk. Bull Yamagata Univ Agric Sci 9:61-70

Tsioulpas A, Grandison AS, Lewis MJ (2007) Changes in physical properties of bovine milk from the colostrum period to early lactation. J Dairy Sci 90:5012-5017

Urashima T, Kitoaka M, Asakuma S, Messer M (2009) Milk oligosaccharides. In: McSweeney PLH, Fox PF (eds) Advanced dairy chemistry, volume 3: lactose, water, salts and minor constituents, 3rd edn. Springer, New York

Uruakpa FO, Ismond MAH, Akobundu ENT (2002) Colostrum and its benefits: a review. Nutr Res 22:755767

Vacher PY, Blum JW (1993) Age-dependency of insulin-like growth factor 1, insulin, protein and immunoglobulin concentrations and gamma-glutamyl-transferase activity in first colostrum of dairy cows. Milchwissenschaft 48:423-426

Walstra P, Jenness R (1984) Dairy chemistry and physics. John Wiley \& Sons, Inc., New York

Walstra P, Wouters JTM, Geurts TJ (2006) Dairy science and technology. Taylor and Francis Group, Boca Raton, FL

Weaver DM, Tyler JW, VanMetre DC, Hostetler DE, Barrington GM (2000) Passive transfer of colostral immunoglobulins in calves. J Vet Intern Med 14:569-577

White JCD, Davies DT (1958a) The relationship between the chemical composition of milk and the stability of the caseinate complex. I. General introduction, description of samples, methods and chemical composition of samples. J Dairy Res 25:236-255

White JCD, Davies DT (1958b) The relation between the chemical composition of milk and the stability of the caseinate complex. II. Coagulation by ethanol. J Dairy Res 25:256-226

White JCD, Davies DT (1958c) The relation between the chemical composition of milk and the stability of the caseinate complex. III. Coagulation by rennet. J Dairy Res 25:267-280

Yagi H, Suzuki S, Noji T, Nagashima K, Kuruome T (1986) Epidermal growth factor in cow's milk and milk formulas. Acta Paediatr Scand 75:233-235

Yamada M, Murakami K, Wallingford JC, Yuki Y (2002) Identification of low-abundance proteins of bovine colostral and mature milk using two-dimensional electrophoresis followed by microsequencing and mass spectrometry. Electrophoresis 23:1153-1160

Yan Y, Fang C, Ye W, Zhou Z (1993) The lipid composition of bovine colostrum. Acta Nutr Sin 15:299-303

Zarcula S, Cernescu H, Mircu C, Tulcan C, Morvay A, Baul S, Popovici D (2010) Influence of breed, parity and food intake on chemical composition of first colostrum in cow. Anim Sci Biotech 43:154-157

Zbikowska A, Dziuba J, Jaworska H, Zaborniak A (1992) The influence of casein micelle size on selected functional properties of bulk milk proteins. Pol J Food Nutr Sci 1:23-32

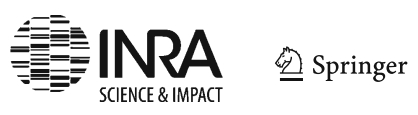


Zhang LY, Wang JQ, Yang YX, Bu DP, Li SS, Zhou LY (2011) Comparative proteomic analysis of changes in the bovine whey proteome during the transition from colostrum to milk. Asian Aus J Anim Sci 24:272278

Zhang NT, Nakano T, Ozimek L (2002) Isolation of lactoferrin from bovine colostrum by SP-Sepharose cation exchange chromatography. Milchwissenschaft 57:11-12

Zhao S, Zhang C, Wang J, Liu G, Bu D, Cheng J, Zhou L (2010) Variations of immunoglobulins in colostrum and immune milk as affected by antigen releasing devices. Asian Aust J Anim Sci 23:1184-1189 